\title{
ЛАТЕНТНОСТЬ ПРЕСТУПЛЕНИЙ, СОВЕРШАЕМЫХ КУРСАНТАМИ ОБРАЗОВАТЕЛЬНЫХ ОРГАНИЗАЦИЙ ФСИН РОССИИ
}

\author{
И. В. Карлов \\ Владимирский юридический институт ФСИН России, г. Владимир, Российская Федерация
}

\author{
Информация о статье \\ Дата поступления \\ 15 марта 2017 г. \\ Дата принятия к печати \\ 26 мая 2017 г. \\ Дата онлайн-размещения \\ 15 сентября 2017 г.
}

\section{Ключевые слова}

Латентность; курсант; студент; образовательная организация; Федеральная служба исполнения наказаний России; показатели; регистрация; фактор; профилактика; воспитание

\begin{abstract}
Аннотация
В структуре преступности обучающихся в образовательных организациях значительную долю составляют латентные преступления, не выявленные правоохранительными органами и администрациями вузов, что затрудняет планирование профилактической работы и ее проведение с обучающимися. В статье анализируются основные подходы к понятию латентности преступлений в отечественной криминологической науке. На основании анализа результатов социологического исследования, решений судебных и правоохранительных органов дается характеристика латентной составляющей преступлений курсантов в вузах Федеральной службы исполнения наказаний России, оцениваются масштабы этого явления. Рассматриваются причины, фракторы и условия неотражения части совершаемых курсантами преступлений в официальном (в том числе ведомственном) учете, связанные с особенностями психологии обучающихся, организацией управления и оценкой работы ведомственных образовательных организаций, информационным обеспечением деятельности уголовно-исполнительной системы. По результатам исследования вносятся предложения по снижению латентной составляющей и повышению эффективности профилактической работы.
\end{abstract}

\section{THE LATENCY OF CRIMES COMMITTED BY CADETS OF EDUCATIONAL INSTITUTIONS OF THE FEDERAL PENITENTIARY SERVICE OF RUSSIA}

\author{
Ilya V. Karlov \\ Vladimir Law Institute, Vladimir, Russian Federation
}

\section{Article info}

Received

March 15, 2017

Accepted

May 26, 2017

Available online

September 15, 2017

\section{Keywords}

The latency; cadet; student; educational institution;

Federal Penitentiary Service of Russia; indicators; registration; factor; prevention; education

\begin{abstract}
Latent crimes committed by students, that are not brought out by the law enforcements and university authorities, are a major part of the overall crime structure. This situation complicates planning and implementing crime preventive actions. The article analyses major approaches to the definition of crime latency that can be found in Russian criminology. Based on the results of sociological surveys, legal decisions produced by judicial and law enforcement authorities, the author characterizes latent component in crimes committed by cadets of Russian Federal penitentiary service institutions and measures the scale of this phenomenon. The author also studies reasons, factors and situations when a number of crimes committed by cadets are not registered in the official (and departmental) records. It happens due to cadets' psychological features, type of management, and performance evaluation of departmental educational institutions and informational support of penitentiary system performance. As a result of this research the author proposes certain measures on reduction of latent component and increase of preventive measures efficiency.
\end{abstract}

В структуре современной преступности значительную долю составляют не выявленные и не учтенные преступления. При этом объективная оценка уровня преступности, ее количественных показателей при отсут- ствии достоверных данных представляется трудно выполнимой, практически невозможной задачей. Как справедливо отмечал Б. Я. Гаврилов, эффрективность контроля над преступностью зависит от реальности задач, 
поставленных перед правоохранительными органами. Это возможно только на основе объективного знания фактического состояния преступности и реального отражения результатов работы правоохранительных органов [1, с. 12-14]. При этом, как указывает Р. М. Акутаев, «все более очевиден разрыв между потребностями науки и практики в полной и достоверной уголовно-статистической информации и ее реальной обеспеченностью» [2, с. 73]. Следовательно, изучение ситуации, связанной с совершением преступлений курсантами образовательных организаций Федеральной службы исполнения наказаний (ФСИН) России, необходимо проводить с учетом латентной составляющей. Получение достоверной иноормации по данному вопросу имеет ключевое значение при принятии управленческих решений: разработке ведомственных программ и планов профилактики правонарушений в вузах, организации профессиональной подготовки сотрудников, определении объемов финансирования и др.

Проблема выявления и учета преступлений в течение многих лет изучалась отечественными и зарубежными учеными. Одним из первых понятие латентной преступности попытался дать В. В. Панкратов, который определил ее как «совокупность преступлений, не выявленных органами милиции, прокуратурой и судом и, соответственно, не нашедших отражение в учете уголовно наказуемых деяний» [3]. Им были названы два признака латентной преступности: невыявленность компетентными органами и неучтенность преступлений уголовно-правовой статистикой. Эти признаки в дальнейшем были признаны основными в отечественной криминологии.

В то же время отдельные криминологи предлагали ограничиться лишь первым признаком. Так, А. С. Шляпочников иГ. И. Забрянский латентными считали преступления, «скрытые от одного из органов, которым по закону предоставлено право расследовать или рассматривать дела о совершенных преступлениях» [4]. Однако в данной позиции не берется в расчет важность учета преступлений для криминологической оценки преступности, имеющихся тенденций и принятия профилактических мер реагирования.

В настоящее время понятие латентной преступности, ее структура, показатели и методы выявления продолжают носить дискуссионный характер. В целом следует отметить, что бо́льшая часть определений строится на основе указанных признаков невыявленности и неучтенности преступлений. Так, по мнению Н. В. Сазоновой, латентная преступность является «частью преступности, выраженной в совокупности преступлений, не вошедших в систему государственного статистического учета, характеризующейся определенными особенностями возникновения и развития, социальным и уголовно-правовым характером, общественной опасностью», кроме того, она имеет «свои качественные и количественные характеристики, временные и пространственные границы» [5, с. 5].

Простое, но емкое определение дает С. М. Иншаков, который характеризует латентную преступность как «незарегистрированную часть фактической преступности» [6].

Р. М. Акутаев делает акцент на ответственности виновных лиц. По его мнению, под латентной преступностью следует понимать «совокупность деяний, не повлекших уголовно-правовых мер реагирования и воздействия со стороны органов, производящих преследование и привлечение виновных лиц к ответственности» [7].

Особо следует отметить точку зрения Ю. А. Шахаева, который дополнительно выделяет в качестве отдельного признака латентной преступности нераскрытие (неполное раскрытие) преступлений [8, с. 23]. В этом отношении его позиция отчасти сходна с воззрениями Р. М. Акутаева. Выделение подобного признака может представлять интерес, поскольку нераскрытие преступлений (даже выявленных) все равно способствует уходу от ответственности виновных лиц, препятствует неотвратимости наказания и «питает» латентную преступность. При этом доля нераскрытых преступлений в России очень высока. Как отмечает М. П. Клейменов, ежегодно около половины преступников по зарегистрированным преступлениям не выявляются и не привлекаются к ответственности. Также, по его мнению, накопленный массив нераскрытых преступлений может рассматриваться материальным свидетельством плохой работы всех правоохранительных органов, системного сбоя по противодействию преступности $[9$, с. $180-181]$.

Применительно к латентной преступности курсантов понятие дает А. М. Панченко, который определяет ее как реальное объективное социально-правовое явление, детерминируемое взаимообусловленным комплексом фракторов, находящихся в курсантской среде, а также в сорерах социально-экономических отношений, правовой и правоприменительной политики, общественного, группового и индивидуального созна- 
ния [10]. Указанное определение является недостаточно полным: справедливо делая акцент на фракторах и условиях совершения курсантами преступлений, А. М. Панченко не включает в него такой признак латентной преступности, как неотражение в учете.

Латентная преступность носит повышенную общественную опасность прежде всего из-за масштабов данного явления, которые, как показывает практика, значительно шире и далеко не адекватны уголовно наказуемым деяниям, учитываемым официальной статистикой [11]. Еще в начале 1970-х гг. сотрудники Всесоюзного научно-исследовательского института по изучению причин и разработке мер предупреждения преступности выявили, что примерно каждый пятый человек из тех, кто совершил уголовное преступление, не подвергается реальному уголовному преследованию [12]. Позднее в результате многолетнего мониторинга латентной преступности, проводимого на основе комплексной исследовательской методики НИИ Генеральной прокуратуры Российской Федерации, было установлено, что действительный уровень преступности более чем в семь раз выше уровня зарегистрированной. При этом 50 \% латентной преступности составляют незаявленные преступления, 40 \% - невыявленные, $10 \%$ - укрытые преступления [13, с. 5; 14]. Аналогичные данные были получены и другими исследователями [15, с. 179].

Кроме того, как отмечает В. В. Гриб, состояние и динамика скрытой (латентной) преступности оказывают существенное негативное влияние на рост количества преступлений и их предупреждение [16]. С одной стороны, как подчеркиваетГ. Ф. Хохряков, опасность латентной преступности заключается в снижении престижа органов уголовной юстиции, неверии в их силы, способность защитить права граждан и обеспечить безопасность общества [17, с. 397]. Применительно к образовательным организациям ФСИН России это приводит к тому, что в ряде случаев потерпевшие курсанты, не веря в эфффективность принимаемых мер реагирования в отношении преступности, выявление виновных в совершении преступлений лиц, или из-за нежелания тратить время на тяжбы с правоохранительными органами, не обращаются к администрации вуза (например, в случаях пропажи личного имущества).

Некоторые криминологи считают, что неполучение гражданами ожидаемой защиты приводит к развитию альтернативных механизмов разрешения криминальных конфлликтов [18]. В частности, в ведомственных вузах это может приводить к несоблюдению правил поведения и неуставным взаимоотношениям: оскорблениям, побоям, причинению различной тяжести вреда здоровью курсантов и иным правонарушениям.

С другой стороны, латентная, безнаказанная преступность является мощным рычагом самодетерминации, источником самовоспроизводства преступности, поскольку преступники, избежавшие изобличения и ответственности, самим фактом безнаказанности стимулируются к продолжению преступной деятельности, а также через механизмы социально-психологического заражения вовлекают новых лиц в орбиту противоправного поведения [19, с. 65]. Примером такой самодетерминации в вузах может служить вовлечение обучающихся в распространение наркотических средств. К тому же фрактическая безнаказанность даже за мелкие нарушения косвенно обусловливает совершение более опасных преступлений.

В целом можно выделить несколько основных причин латентности преступлений курсантов вузов ФСИН России, вследствие которых они не отражаются в учете, причем такие преступления имеют место на самых разных уровнях.

Первой причиной является необращение курсантов, потерпевших от правонарушений, к администрации вуза и в правоохранительные органы (незаявленная преступность). Как отмечает А. М. Панченко, в отличие от преступлений с общим субъектом, в которых значительный удельный вес в структуре латентной преступности принадлежит «преступлениям без потерпевших», в курсантской среде такая доля незначительна - фактические потерпевшие больше склонны к замалчиванию фракта преступного посягательства на них [20]. Причиной этого может быть как неверие в эфффективность разбирательства (например, при хищениях имущества), так и страх перед местью правонарушителя.

В немалой степени латентности способствует пассивное отношение отдельных категорий курсантов к совершаемым преступлениям и нарушениям служебной дисциплины. Как отмечает Ю. П. Оноколов, с правовой стороны пассивность может выступать специфрическим нарушением дисциплины, влекущим в определенных случаях и уголовную ответственность [21]. Страх ответственности, ненадлежащая гражданская позиция и низкая правовая культура отдельных категорий курсантов, а также корпоративная солидарность приводят к тому, что в ряде случаев они не принимают меры к пресечению нарушений 
сокурсников или не докладывают о них руководству, чем способствуют сокрытию значительной части нарушений.

Так, в результате исследования,проведенного в 2016 г. во Владимирском юридическом институте ФСИН России, было установлено, что 48,9 \% опрошенных курсантов лично сталкивались с хищением денежных средств и иного имущества, 31,1 \% - с нанесением побоев и причинением вреда здоровью различной степени тяжести, 15,6 \% - с незаконным оборотом наркотических средств, 13,3 \% - с распространением экстремистских материалов (в том числе в социальных сетях $)^{1}$. В целом же, как отмечают исследователи, в структуре незарегистрированной (латентной) преступности курсантов ведомственных вузов преобладают деяния небольшой и средней тяжести, связанные в основном с бытовыми проблемами и с уклонением от несения службы [20]. Применительно же к вузам ФСИН России можно говорить также о значительной доле преступлений в сорере незаконного оборота наркотических средств, составляющей только по официальным данным ведомственной статистики около половины всех выявленных преступлений².

Как справедливо указывает А. М. Панченко, «субкультура курсантского сообщества не поощряет выявление самими курсантами девиантных и делинквентных социальных практик. Напротив, такие действия осуждаются, и курсанты, которые способствуют раскрытию правонарушений различного рода, получают непривлекательный социальный статус. В отношении таких курсантов используются практики социального исключения и изоляции» [там же]. Примечательно, что и по результатам проведенного исследования 64,6 \% опрошенных указали, что вероятнее всего курсанты не подадут рапорт руководству подразделения или вуза об известных им нарушениях. При этом 22,8 \% курсантов при возникновении у них каких-либо неприятностей предпочитают обращаться за помощью к другим курсантам, а не к администрации вуза, а 29,1\% вовсе отметили, что вряд ли к кому-либо обратятся. Возможность обращения в подразделения собственной безопасности фСИН России (для дальнейшей уголовно-правовой оценки действий нарушителей) отметили лишь 1,3\% опрошенных.

1 В опросе принимали участие 164 курсанта 1-5-го курсов юридического факультета ВЮИ фСИН России. Некоторые вопросы предполагали несколько вариантов ответов.

${ }^{2}$ См.: Отчеты ФСИН России по фоормам 3-Д, 3-ПР и ФСИН-7 (работа с личным составом - разделы 03, 04) за период 2009-2016 гг.
Второй причиной является сокрытие информации о выявленных нарушениях руководителями всех уровней (взводов, курсов, факультетов) от руководства вуза. С одной стороны, это общая проблема всех правоохранительных органов, связанная со спецификой оценки их деятельности. Как отмечает Я.И. Гилинский, причина подобного поведения в правоохранительных органах - стремление скрыть истинные масштабы преступности, борьба за «честь мундира», желание «выслужиться», а то и выполнение прямого приказа «сверху» [22, с. 98-100]. О корпоративной солидарности, круговой поруке сотрудников (работников) учреждений уголовно-исполнительной системы, их стремлении разобраться своими силами и средствами, «не вынося сор из избы», низкой заинтересованности руководителей в огласке фактов совершения личным составом преступлений говорит и А. В. Яковлев [23]. Ранее многие нарушения в учреждениях уголовно-исполнительной системы (УИС) становились известными лишь в случае наступления опасных последствий, прямого вмешательства правоохранительных и контролирующих органов и вышестоящих должностных лиц. В настоящее время в связи с повышением гласности в деятельности государственных структур и внимания к кадровым проблемам правоохранительных органов наблюдаются положительные тенденции по повышению прозрачности работы учреждений и органов УИС, хотя говорить о коренном переломе ситуации, безусловно, преждевременно.

С другой стороны, важную роль играет специфика управления в самих ведомственных вузах, во многом сходная с организацией службы в воинских частях. Естественно, состояние преступности в курсантских подразделениях в первую очередь зависит от отношения к служебным обязанностям их начальников. Однако в то же время, как отмечает Ю. П. Оноколов, проблема не только в профессиональных способностях офицеров, поскольку обычно командиру выгоднее скрыть правонарушение, чем допустить его расследование, так как это может негативно отразиться на его карьере [24].

Проведение профилактической работы, воспитание подчиненного личного состава, необходимость доклада вышестоящему руководству о происшествиях закреплены в должностных обязанностях начальников самого разного уровня. При этом за нарушение указанных обязанностей, ненадлежащий контроль за подчиненными курсантами предусмотрена ответственность. Привлече- 
ние к дисциплинарной ответственности руководителей при возникновении чрезвычайных происшествий с участием подчиненного личного состава вообще является достаточно распространенной практикой в правоохранительных органах в рамках разбирательств и служебных проверок, проводимых в целях поиска причин и условий случившегося ${ }^{3}$. В отдельных случаях непривлечение администрации вуза к дисциплинарной ответственности при совершении курсантом ФСИН России нарушения вообще служило основанием для отмены вынесенных решений за мягкостью принятых мер ${ }^{4}$.

Конечно, в целом для руководителей это является важным стимулирующим фактором. Однако важно, чтобы решение о привлечении к ответственности было принято не фрормально, по фракту совершения подчиненным преступления, а с учетом «тяжести совершенного проступка и степени вины руководителя» 5 . В противном случае репрессивные меры могут только способствовать повышению латентности совершаемых в вузах преступлений. К тому же процент сокрытия правонарушений руководителями на порядок ниже, чем самими курсантами. Так, на вопрос о том, сталкивались ли курсанты со случаями сокрытия фрактов нарушений руководством подразделения, лишь 7,7 \% ответили положительно, а, к примеру, со случаями сокрытия нарушений младшими командирами (командирами отделений, заместителями командиров взводов из числа курсантов) и рядовыми курсантами эти показатели составили 25,4 и 38,0 \% соответственно.

Низкая заинтересованность в огласке фактов совершения преступлений в образовательной организации ФСИН России объясняется не только возможными негативными последствиями для руководителей. В силу сложившейся социальной практики выявленные преступления курсантов получают повы-

3 См., напр.: Начальство подмосковного экс-полицейского уволили из-за ДТП с четырьмя жертвами [Электронный ресурc]. URL: http://www.interfax.ru/ russia/529997; По подозрению в совершении преступления задержаны курсанты Белгородского юридического института МВД [Электронный ресурс]. URL: https:// мвд.pф/news/item/145524.

${ }^{4}$ См.: Решение Левобережного районного суда г. Воронежа по делу № 2-1434/2011 9-1584/2011 от 26 сентября 2011 г. [Электронный ресурс]. URL: https: //levoberezhny--vrn.sudrf.ru.

5 См.: Инструкция о порядке применения Положения о службе в органах внутренних дел Российской Федерации в учреждениях и органах уголовно-исполнительной системы : утв. приказом Минюста России от 6 июня 2005 г. № 76. Пункт 13.4 // Бюллетень нормативных актов федеральных органов исполнительной власти. 2005. № 27. шенный общественный резонанс («оборотни в погонах»), активно обсуждаются в средствах массовой информации, что негативно сказывается на имидже учебного заведения и, например, может привести к невыполнению плана набора и иным трудностям. Кроме того, состояние правопорядка и дисциплинарная практика являются важными направлениями оценки деятельности вуза при проведении инспектирования. В определенных случаях совершение личным составом преступления вообще может привести к признанию деятельности вуза неудовлетворительной ${ }^{6}$.

Третьей причиной латентности является несовершенство системы ведомственной статистической отчетности. Здесь, правда, речь идет не о латентности в классическом понимании (поскольку меры реагирования правоохранительными органами к нарушителям применяются), а скорее как о факторе, осложняющем оценку масштабов этого явления в силу неизвестности принимаемых мер и, соответственно, затрудняющем профиилактику.

В течение многих лет во ФСИН России сведения о нарушениях законности и преступлениях, совершаемых сотрудниками УИС, отражались в форме статистической отчетности 3-ПР, которая в связи с изменением законодательства существенно устарела и лишь затрудняла деятельность сотрудников ${ }^{7}$. Ранее на ряд недостатков в организации учета уже обращалось внимание [25]. С введением нового порядка и формы предоставления сведений ФСИН-7 «Кадровое обеспечение деятельности УИС» (разделы 03, 04) был исправлен целый ряд недостатков ${ }^{8}$.

Как положительный момент для вузов ФСИН России следует отметить введение отдельного учета образовательных организаций, дифференциацию и конкретизацию переменного состава, расширение состава учитываемых преступлений (выделение ст. 159 Уголовного кодекса Российской Федерации «Мошенничество»). Особо следует

${ }^{6}$ См., напр.: Об утверждении Порядка организации работы по инспектированию деятельности образовательных учреждений Федеральной службы исполнения наказаний : приказ ФСИН России от 28 авг. 2010 г. № 385 // Бюллетень нормативных актов федеральных органов исполнительной власти. 2010. № 50 ; Об утверждении временной методики оценки служебной деятельности в уголовно-исполнительной системе [Электронный ресурс] : распоряжение ФСИН России от 25 мая 2016 г. № 54-р. URL: http: / /15.fsin.su/normativno-pravovye-akty.

7 Об упорядочении сбора и обработки статистической отчетности по работе с личным составом [Электронный ресурс] : приказ фСИН России от 23 нояб. 2006 г. № 748 / / СПС «КонсультантПлюс».

8 Введена приказом ФСИН России от 14 октября 2015 г. № 949 // Там же. 
указать конкретизацию в отчетной форме отдельных этапов расследования (возбуждение уголовного дела, привлечение в качестве обвиняемого и вынесение приговора судом), позволяющую проводить более полный анализ привлечения лиц к уголовной ответственности; введение дополнительного учета вынесенных приговоров по делам, возбужденным в предыдущих периодах (ранее принимались во внимание до конца отчетного периода), а также осуществление учета уже на этапе возбуждения уголовного дела (ранее рассматривались на этапе предъявления обвинения, когда лицо, как правило, уже было уволено из УИС и поэтому указанные сведения в отчете не отражались).

Вообще неотражение в ведомственном учете лиц, в отношении которых были возбуждены уголовные дела, поскольку они уже уволены со службы, является общей проблемой в правоохранительных органах, способствующей повышению латентной составляющей. Это касается не только так называемых увольнений «задним числом», прямо нарушающих законодательство. Будучи достаточно распространенной практикой в правоохранительных органах в прежние годы, в настоящее время в связи с повышенным вниманием органов управления и общественности к подобного рода явлениям они представляют собой скорее постыдное исключение, за которое руководители, допустившие его, могут понести ответственность вплоть до увольнения со службы ${ }^{9}$.

Здесь прежде всего речь идет о случаях увольнения курсантов из УИС (или отчисления из вуза с последующим откомандированием в комплектующий орган) по иным основаниям: в связи с нарушением условий контракта, выпуском из вуза, невыполнением учебного плана, нарушением служебной дисциплины и иным причинам, не связанным с совершением преступления и вступлением в законную силу обвинительного приговора суда, когда на момент возбуждения уголовного дела лицо уже не является курсантом образовательной организации ФСИН России, а в ряде случаев может даже проходить службу совсем в других ведомствах (чаще всего в МВД России).

9 См., напр.: Вопреки министру: подозреваемый в убийстве прохожего подмосковный полицейский уволен задним числом, его начальников наказали [Электронный ресурc]. URL: http://vz.ru/society/ 2012/6/15/583867.html; Глава Свердловского УфМС предупрежден прокуратурой о неполном служебном соответствии [Электронный ресурс]. URL: http:// vedomosti-ural.ru/news/49597.
Так, в 2011 г. за незаконный оборот наркотических средств были задержаны и осуждены сотрудники полиции С. и У. При этом, согласно материалам дела, преступления были совершены еще в период обучения в образовательной организации ФСИН России. В 2015 г. курсанты-выпускники, отмечая окончание обучения, нанесли побои жителям г. Новокузнецка, некоторые из них были доставлены в больницу. В 2014 г. курсант К. на выпуске совершил дорожно-транспортное происшествие, в результате которого здоровью курсанта С. был причинен тяжкий вред. В ноябре 2014 г. был вынесен обвинительный приговор гр. 3. , совершившему в период обучения в вузе ФСИН России преступления, связанные с незаконным оборотом наркотиков (за полгода до этого был отчислен из вуза и уволен из уголовно-исполнительной системы за прогул учебных занятий). Естественно, эти и другие подобные случаи в ведомственную статистику не попадают ${ }^{10}$.

Как недостаток системы учета также следует отметить низкую доступность статистических данных. В соответствии с ведомственными нормативными правовыми актами и по сложившейся в УИС практике все статистические данные направляются в Федеральное казенное учреждение «Научно-исследовательский институт информационных технологий Федеральной службы исполнения наказаний» (г. Тверь), которое занимается их проверкой, дальнейшим обобщением и направлением во ФСИН России. Доступ к указанным данным впоследствии осуществляется через специализированное программное обеспечение, только с отдельных компьютеров и в сокращенной форме (например, без предоставления пояснительных записок, расшифровывающих отчетные данные). В ряде случаев доступ к ним требует направления письменного запроса и согласования с курирующим подразделением ФСИН России. Ограничен доступ и к электронной базе данных «Учет преступлений среди личного

10 Подробнее см.: Бывший сотрудник полиции осужден за незаконный оборот наркотиков [Электронный ресурс] // Управление Следственного комитета Рф по Владимирской области : офиц. сайт. URL: http://vladimir.sledcom.ru/news/item/750543; Руководство КИ ФСИН разберется в конфликте с участием курсантов в Новокузнецке [Электронный ресурс]. URL: http://kuzbass-today.ru/social/9468-руководство-ки-фрсин-разберется-в-конф.html ; Решение Ковровского городского суда Владимирской области по делу №2-3901 / 2015 от 11 ноября 2015 г. [Электронный ресурс]. URL: http: //kovrovsky.wld.sudrf.ru ; Приговор Ленинского районного суда Владимирской области по делу № 1-250/2014 от 27 октября 2014 г. [Электронный ресурс]. URL: http://leninsky.wld.sudrf.ru. 
состава уголовно-исполнительной системы» ${ }^{11}$. Офрициальные интернет-сайты учреждений и органов в части, касающейся совершаемых личным составом преступлений и правонарушений, также малоинорормативны (опять же по указанным причинам имиджевого характера).

Указанные обстоятельства создают трудности при проведении сравнительного анализа положения дел в учреждениях и органах УИС как со стороны сотрудников, осуществляющих профилактическую работу, так и со стороны научного сообщества, занимающегося исследованием состояния дисциплины и законности в органах государственной власти. Следует отметить, что данная проблема носит межведомственный характер. Например, на необходимость повышения доступности сведений о правонарушениях с участием личного состава, совершенствования информационно-правового обеспечения деятельности вооруженных сил, правоохранительных органов и судов, а также создания единой информационной базы как средства снижения латентности преступлений военнослужащих указывает Ю. П. Оноколов [26; 27].

Таким образом, анализ статистических данных, положений нормативных правовых актов и результатов социологического исследования позволяет сделать следующие выводы:

1. Работа по профилактике преступлений и правонарушений в вузах ФСИН России требует обязательного учета латентной составляющей, которая составляет значительную (а вероятнее, большую) часть фрактически

11 О создании электронной базы данных «Учет преступлений среди личного состава уголовно-исполнительной системы» : приказ ФСИН России от 14 марта 2008 г. № 150 / / Ведомости уголовно-исполнительной системы. 2008. № 7. совершаемых курсантами преступлений. Без организации надлежащего предупреждения, выявления всей фрактической, и особенно латентной, преступности и борьбы с ней невозможно реальное снижение числа совершаемых курсантами преступлений, укрепление законности и служебной дисциплины и правопорядка в образовательных организациях.

2. Под латентной преступностью следует понимать совокупность преступлений курсантов (бывших курсантов), совершенных ими в период прохождения обучения в образовательных организациях ФСИН России, не выявленных правоохранительными органами или сокрытых от учета (в том числе ведомственного).

3. Сокрытию значительной части нарушений способствуют пассивность, ненадлежащая гражданская позиция и низкая правовая культура отдельных категорий курсантов, а также корпоративная солидарность обучающихся.

4. Негативное влияние на выявление преступлений и правонарушений играет система оценки деятельности руководителей подразделений и вузов, а также недостатки ведомственной системы учета правонарушаемости.

5. Совершенствованию системы профилактической работы и информационно-правового обеспечения в вузах фСИН России способствовало бы повышение доступности аналитических и статистических данных о совершаемых правонарушениях в учреждениях и органах УИС.

Решение указанных проблем окажет положительное влияние на качество подготовки курсантов, а следовательно, и на состояние законности в учреждениях и органах правоохранительной системы, в которые курсанты будут направлены для дальнейшего прохождения службы после выпуска из образовательных организаций.

\section{СПИСОК ИСПОЛЬЗОВАННОЙ ЛИТЕРАТУРЫ}

1. Гаврилов Б. Я. Латентная преступность: понятие, структура, факторы латентности и меры обеспечения достоверности уголовной статистики / Б. Я. Гаврилов. - 2-е изд., перераб. и доп. - М. : ТК Велби : Проспект, 2007. - 120 с.

2. Акутаев Р. М. Криминологический анализ латентной преступности : дис. ... д-ра юрид. наук : 12.00.08/ Р. М. Акутаев. - СПб.: Изд-во С.-Петерб. ун-та МВД России, 1999. - 358 с.

3. Панкратов В. В. Косвенные методы изучения преступности / В. В. Панкратов / / Вопросы борьбы с преступностью : материалы 2-й науч. конф. аспирантов и соискателей. - М., 1967. - С. 7-11.

4. Шляпочников А. С. Выявление латентной преступности / А. С. Шляпочников, Г.И.Забрянский / / Советское государство и право. - 1971. - № 5. - С. 99-101.

5. Сазонова Н. В. Латентная преступность: понятие, причины, измерение : автореф. дис. ... канд. юрид. наук : 12.00 .08 / Н. В. Сазонова. - Красноярск, 2004. - 19 с.

6. Теоретические основы исследования и анализа латентной преступности / под ред. С. М. Иншакова. М. : Юнити-Дана, 2011. - 839 с.

7. Акутаев Р. М. Латентная преступность: актуальность, проблемы и понятие / Р. М. Акутаев// Государство и право. - 1997. - № 12. - С. 79-88.

8. Шахаев Ю. А. Противодействие латентной преступности в Республике Дагестан / Ю. А. Шахаев. — Махачкала : АЛЕФ, 2014. - 196 с. 
9. Клейменов М. П. Детерминанты нераскрытой преступности / М. П Клейменов / В Вестник Омского университета. Сер.: Право. — 2013. - № 3 (36). - С. 179-189.

10. Панченко А. М. Предупреждение преступлений, совершаемых курсантами высших военно-учебных заведений : автореф. дис. ... канд. юрид. наук : 12.00 .08 / А. М. Панченко. - М., 2011. - 26 с.

11. Огородников В. В. Латентная преступность и взаимодействие правоохранительных органов с населением / В. В. Огородников / / Латентная преступность: познание, политика, стратегия: материалы междунар. семинара. - М. : Изд-во ВНИИ МВД России, 1993. - С. 170-182.

12. Курляндский В. И. Неотвратимость наказания и борьба с преступностью / В. И. Курляндский / / Советское государство и право. - 1972. - № 9. - С. 81-83.

13. Иншаков С. М. Исследование криминальной латентности и парадоксы социального отрицания преступности / С. М. Иншаков / / Криминологический журнал Байкальского государственного университета экономики и права. - 2008. - № 4. - С. 5-10.

14. Иншаков С. М. Латентная преступность как объект исследования / С. М. Иншаков / / Исследования латентной преступности : материалы круглого стола. - М. : Акад. Генер. прокуратуры РФ, 2010. - С. 6-13.

15. Кондратюк Л. В. Криминологическое измерение / Л. В. Кондратюк, В. С. Овчинский. - М. : Норма, 2008. $-272 \mathrm{c}$.

16. Гриб В. В. Социально-криминологическая природа искусственно латентной преступности современной России и фракторы, ее детерминирующие / В. В. Гриб // Юридический мир. - 2013. - № 6. - С. 21-24.

17. Хохряков Г. Ф. Криминология / Г. Ф. Хохряков. - М. : Юристъ, 1999. - 511 с.

18. Ефименко М. О. Криминологическая теория и практика в организации ведомственного контроля за достоверностью уголовной статистики / М. О. Ефименко, Р. В. Скоморохов, В. Н. Шиханов. - М. : ВолтерсКлувер, 2010. - 278 с.

19. Горяинов К. К. Латентная преступность в России: опыт теоретического и прикладного исследования / К. К. Горяинов, А. П. Исиченко, Л. В. Кондратюк. - М. : Изд-во ВНИИ МВД РФ, 1994. - 152 с.

20. Панченко А.М. Латентность преступлений, совершаемых курсантами высших военно-учебных заведений / А. М. Панченко / / Российский следователь. - 2011. - № 10. - С. 22-24.

21. Оноколов Ю. П. Осуществление деятельности по предупреждению преступности в армии требует учета латентных преступлений / Ю. П. Оноколов / / Военно-юридический журнал. — 2011. — № 3. - С. 15-19.

22. Гилинский Я. И. Девиантология: социология преступности, наркотизма, проституции, самоубийств и других «отклонений» / Я. И. Гилинский. - СПб. : Юрид. центр Пресс, 2004. - 520 с.

23. Яковлев А. В. Факторы латентности преступлений, совершаемых в учреждениях уголовно-исполнительной системы России / А. В. Яковлев // Уголовно-исполнительная система: право, экономика, управление. - 2007. - № 6. - С. 11-13.

24. Оноколов Ю. П. О латентности преступлений, сопряженных с применением насилия, в армейской среде / Ю. П. Оноколов / / Военно-юридический журнал. - 2011. - № 1. - С. 14-18.

25. Карлов И. В. Некоторые проблемы учета и анализа преступлений, совершаемых курсантами образовательных организаций ФСИН России / И. В. Карлов // Вестник Владимирского юридического института. 2016. - № 2. - С. 21-23.

26. Оноколов Ю. П. Выявлению и профилактике латентных преступлений в армии поможет общая информационная база / Ю. П. Оноколов / / Военно-юридический журнал. - 2010. - № 9. - С. 2-5.

27. Оноколов Ю. П. Необходима общая информационная база правоохранительных органов и судов / Ю. П. Оноколов / / Российская юстиция. - 2010. - № 10. - С. 58-61.

\section{REFERENCES}

1. Gavrilov B. Ya. Latentnaya prestupnost': ponyatie, struktura, faktory latentnosti i mery obespecheniya dostovernosti ugolovnoi statistiki [Latent Crime: Notion, Structure, Latent Factors and Measures of Making Criminal Statistics Verifiable]. $2^{\text {nd }}$ ed. Moscow, TK Velbi Publ., Prospekt Publ., 2007.120 p.

2. Akutaev R. M. Kriminologicheskii analiz latentnoi prestupnosti. Dokt. Diss. [Criminological Analysis of Latent Crime. Doct. Diss.]. Saint Petersburg State Legal Institute of the Ministry of Internal Affairs of the Russian Federation Publ., 1999. 358 p.

3. Pankratov V. V. Indirect Methods of Research into Crime. Kosvennye metody izucheniya prestupnosti. Voprosy bor'by s prestupnost'yu. Materialy 2-i nauchnoi konferentsii aspirantov i soiskatelei [lssues on Combating Crime. Papers of the $2^{\text {nd }}$ research conference of postgraduate students and applicants]. Moscow, 1967, pp. 7-11. (In Russian).

4. Shlyapochnikov A. S., Zabryanskii G. I. Detection of Latent Crime. Sovetskoe gosudarstvo i pravo = Soviet State and Law, 1971, no. 5, pp. 99-101. (In Russian).

5. Sazonova N. V. Latentnaya prestupnost': ponyatie, prichiny, izmerenie. Avtoref. Kand. Diss. [Latent Crime: Notion, Reasons, and Measurement. Cand. Diss. Thesis]. Krasnoyarsk, 2004.19 p.

6. Inshakov S. M. (ed.). Teoreticheskie osnovy issledovaniya i analiza latentnoi prestupnosti [Theoretical Grounds of Research and Analysis of Latent Crime]. Moscow, Yuniti-Dana Publ., 2011. 839 p.

7. Akutaev R. M. Latent Crime: Relevance, Problems and Notion. Gosudarstvo i pravo = State and Law, 1997, no. 12, pp. 79-66. (In Russian).

8. Shakhaev Yu. A. Protivodeistvie latentnoi prestupnosti v Respublike Dagestan [Fighting against Latent Crime in the Republic of Dagestan]. Makhachkala, ALEF Publ., 2014. 196 p.

9. Kleimenov M. P. The causations of undetection crime. Vestnik Omskogo universiteta. Seriya: Pravo= Herald of Omsk University. Series: Law, 2013, no. 3 (36), pp. 179-189. (In Russian). 
10. Panchenko A. M. Preduprezhdenie prestuplenii, sovershaemykh kursantami vysshikh voenno-uchebnykh zavedenii. Avtoref. Kand. Diss. [Prevention of Crimes Committed by Cadets of Military Educational Institutions. Cand. Diss. Thesis]. Moscow, 2011. 26 p.

11. Ogorodnikov V. V. Latent crime. Cooperation of Law Enforcement Agencies and Residents. Latentnaya prestupnost': poznanie, politika, strategiya. Materialy mezhdunarodnogo seminara [Latent Crime: Notion, Policy, Strategy. International seminar papers]. Moscow, Ministry of Internal Affairs of Russian Federation All-Russian Research Institute Publ., 1993, pp. 170-182. (In Russian).

12. Kurlyandskii V. I. Certainty of Punishment and Fight against Crime. Sovetskoe gosudarstvo $i$ pravo $=$ Soviet State and Law, 1972, no. 9, pp. 81-83. (In Russian).

13. Inshakov S. M. Research of criminal latency and paradoxes of social denial of criminality. Criminology Journal of Baikal National University of Economics and Law, 2008, no. 4, pp. 5-10. (In Russian).

14. Inshakov S. M. Latent Crime as an Object of Research. Issledovaniya latentnoi prestupnosti. Materialy kruglogo stola [Research of latent crime. Papers of panel discussion]. Moscow, Academy of the Office of the Prosecutor General of the Russian Federation Publ., 2010, pp. 6-13. (In Russian).

15. Kondratyuk L. V., Ovchinskii V. S. Kriminologicheskoe izmerenie [Criminological Dimension]. Moscow, Norma Publ., 2008. 272 p.

16. Grib V. V. Social and Criminological Nature of Artificially Latent Crime in Modern Russia and its Determining Factors. Yuridicheskiy mir $=$ The Legal World, 2013, no. 6, pp. 21-24. (In Russian).

17. Khokhryakov G. F. Kriminologiya [Criminology]. Moscow, Yurist Publ., 1999. 511 p.

18. Efimenko M. O., Skomorokhov R. V., Shikhanov V. N. Kriminologicheskaya teoriya i praktika v organizatsii vedomstvennogo kontrolya za dostovernost' yu ugolovnoi statistiki [Criminological Theory and Practice in Organizing Departmental Control Over Crime Statistics]. Moscow, Volters Kluver Publ., 2010. 278 p.

19. Goryainov K. K., Isichenko A. P., Kondratyuk L. V. Latentnaya prestupnost' v Rossii: opyt teoreticheskogo i prikladnogo issledovaniya [Latent Crime in Russia: Results of Theoretical and Applied Research]. Moscow, Ministry of Internal Affairs of Russian Federation All-Russian Research Institute Publ., 1994. 152 p.

20. Panchenko A. M. Latency of Crimes Committed by Cadets of Higher Military Educational Institutions. Rossiiskii sledovatel' = Russian Investigator, 2011, no. 10, pp. 22-24. (In Russian).

21. Onokolov Yu. P. Actions on Preventing Crimes in Armed Forces Require Registration of Latent Crimes. Voenno-yuridicheskiy zhurnal = Military-law Journal, 2011, no. 3, pp. 15-19. (In Russian).

22. Gilinskii Ya. I. Deviantologiya: sotsiologiya prestupnosti, narkotizma, prostitutsii, samoubiistv i drugikh "otklonenii» [Deviance study: Sociology of Crime, Drug Addiction, Prostitution, Suicides and Other «Deviations»]. Saint Petersburg, Yuridicheskii tsentr Press Publ., 2004. 520 p.

23. Yakovlev A. V. Factors of Crime Latency Committed in Russian Penal System Institutions. Ugolovno-ispolnitel'naya sistema $=$ Correctional System, 2007, no. 6, pp. 11-13. (In Russian).

24. Onokolov Yu. P. On Latency of Violent Crimes in the Army. Voenno-yuridicheskiy zhurnal = Military-law Journal, 2011, no. 1, pp. 14-18. (In Russian).

25. Karlov I. V. Some problems of accounting and analysis of crimes committed by cadets of educational institutions of the FPS of Russia. Vestnik Vladimirskogo yuridicheskogo instituta = Vladimir Law Institute Bulletin, 2016, no. 2, pp. 21-23. (In Russian).

26. Onokolov Yu. P. A Common Information Database Will Aid in Identification and Prevention of Latent Crimes in the Army. Voenno-yuridicheskiy zhurnal= Military-law Journal, 2010, no. 9, pp. 2-5. (In Russian).

27. Onokolov Yu. P. We Need a Common Information Database of Law Enforcement Bodies and Courts. Rossiiskaya yustitsiya $=$ Russian Justice, 2010, no. 10, pp. 58-61. (In Russian).

\section{Информация об авторе}

Карлов Илья Викторович - адъюнкт очного обучения, Владимирский юридический институт, 600020, г. Владимир, ул. Б. Нижегородская, 67 е, e-mail: vsegdayspexkiv@yandex.ru.

\section{Для цитирования}

Карлов И. В. Латентность преступлений, совершаемых курсантами образовательных организаций ФСИН России / И. В. Карлов / / Известия Байкальского государственного университета. - 2017. T. 27, № 3. - C. 434-442. - DOI: $10.17150 / 2500$ 2759.2017.27(3).434-442.

\section{Author}

llya V. Karlov - Post-graduate student, Vladimir Law Institute, 67 e, B. Nizhegorodskaja St., 600020, Vladimir, Russian Federation, e-mail: vsegdayspexkiv@ yandex.ru.

\section{For Citation}

Karlov I. V. The Latency of Crimes Committed by Cadets of Educational Institutions of the Federal Penitentiary Service of Russia. Izvestiya Baykal'skogo gosudarstvennogo universiteta $=$ Bulletin of Baikal State University, 2017, vol. 27, no. 3, pp. 434-442. DOl: 10.17150/2500-2759.2017.27(3).434-442. (In Russian). 